\title{
Factors Affecting Cyperus difformis Seed Germination and SEEDLING EMERGENCE ${ }^{1}$
}

\author{
Fatores que Afetam a Germinação de Sementes e a Emergência de Plântulas de Cyperus \\ difformis
}

\author{
DERAKHSHAN, A. ${ }^{2}$ and GHEREKHLOO, J. $^{2}$
}

\begin{abstract}
Specific knowledge about the dormancy, germination, and emergence patterns of weed species aids the development of integrated management strategies. Laboratory studies were conducted to determine the effect of several environmental factors on seed germination and seedling emergence of Cyperus difformis. Germination of freshly harvested seeds was inhibited by darkness; however, when seeds were subsequently transferred to complete light they germinated readily. Our results showed that $2 \mathrm{wk}$ of cold stratification overcome the light requirement for germination. Seeds of $C$. difformis were able to germinate over a broad range of temperatures $\left(25 / 15,30 / 20,35 / 25\right.$, and $40 / 30{ }^{\circ} \mathrm{C}$ day/night). The response of germination rate to temperature was described as a non-linear function. Based on model outputs, the base, the optimum and the ceiling temperatures were estimated as $14.81,37.72$ and $45^{\circ} \mathrm{C}$, respectively. A temperature of $120{ }^{\circ} \mathrm{C}$ for a $5 \mathrm{~min}$ was required to inhibit $50 \%$ of maximum germination. The osmotic potential and salinity required for $50 \%$ inhibition of maximum germination were $-0.47 \mathrm{MPa}$ and $135.57 \mathrm{mM}$, respectively. High percentage of seed germination (89\%) was observed at $\mathrm{pH}=6$ and decreased to $12 \%$ at alkaline medium (pH 9) $\mathrm{pH}$. Seeds sown on the soil surface gave the greatest percentage of seedling emergence, and no seedlings emerged from seeds buried in soil at depths of $1 \mathrm{~cm}$.
\end{abstract}

Keywords: osmotic potential, salinity stress, $\mathrm{pH}$, soil depth, temperature.

RESUMO - O conhecimento específico sobre os padrões de dormência, germinação e emergência de espécies de plantas daninhas auxilia o desenvolvimento de estratégias integradas de gestão. Foram realizados estudos de laboratório para determinar o efeito de vários fatores ambientais na germinação de sementes e emergência de plântulas de Cyperus difformis. A germinação das sementes recémcolhidas foi inibida pela escuridão; no entanto, quando as sementes foram transferidas posteriormente para a luz total, germinaram prontamente. Nossos resultados mostraram que duas semanas de estratificação fria superam o requisito de luz para a germinação. As sementes de C. difformis conseguiram germinar numa ampla gama de temperaturas (25/15, 30/20, 35/25, e 40/30 ${ }^{\circ} \mathrm{C} \mathrm{dia/}$ noite). A resposta da taxa de germinação à temperatura foi descrito como uma função não-linear. Com base em resultados do modelo, as temperaturas de base, ótima e e teto foram estimadas em 14,81, 37,72 e $45^{\circ} \mathrm{C}$, respectivamente. Foi preciso uma temperatura de $120^{\circ} \mathrm{C}$ por mais 5 minutos para inibir 50\% da germinação máxima. O potencial osmótico e a salinidade necessários para uma inibição de 50\% da máxima germinação foram-0,47 MPa e 135,57 mM, respectivamente. Foi observada uma alta percentagem de germinação das sementes (89\%) com $\mathrm{pH}=6$, a qual diminuiu para $12 \%$ em meio alcalino $(\mathrm{pH}$ ) de $\mathrm{pH}$. As sementes semeadas na superficie do solo resultaram na maior porcentagem de emergência de plântulas, e nenhuma plântula emergiu a partir de sementes enterradas no solo a uma profundidade de $1 \mathrm{~cm}$.

Palavras-chave: potencial osmótico, estresse salino, $\mathrm{pH}$, profundidade do solo, temperatura.

1 Recebido para publicação em 25.9.2012 e aprovado em 26.11.2012.

2 Gorgan University of Agricultural Sciences and Natural Resources (GUASNR), Gorgan, Iran, <derakhshan.abo@gmail.com>. 


\section{INTRODUCTION}

Cyperus difformis is a species of sedge known by several common names, including variable flatsedge and smallflower umbrellasedge. This plant is native to southern Europe, most of Africa, Asia, and Australia, and it is naturalized in other areas of the world (Holm et al., 1991). It is a prolific seed producer, which normally grows in flooded or very moist soils. This plant is primarily a weed of paddy or flooded rice, and it is a weed of rice in 46 countries (Rao et al., 2007). It is frequently found in small pools, along rivers, canals, and streams, in open wet places, and in grassy swamps. It grows best in rich, fertile soils, but it can also grow in poorer sandy or clay soils of unused lands or in fallow rice fields (Holm et al., 1991; Chauhan \& Johnson, 2009a). The ability of the species to complete a vegetative and reproductive cycle within a month or so makes it especially competitive in a crop that requires at least 90 or more days to reach maturity (Holm et al., 1991).

Seed germination is a key event in determining the success of a weed in an agro-ecosystem and it may be regulated by several factors, including temperature, light, soil salinity, moisture, and $\mathrm{pH}$. Dormancy status influences the germination of seeds in light and dark. Non-dormant seeds of some species germinate more readily under light than under dark conditions (Baskin \& Baskin, 1998). Temperature plays a major role in determining the periodicity of seed germination and the distribution of species (Guan et al., 2009). Germination rate usually increases linearly with temperature, at least within a well-defined range, and declines sharply at higher temperatures (Alvarado $\&$ Bradford, 2002). Knowledge of the effect of constant and alternating temperatures on $C$. difformisgermination can help us understand its emergence pattern and its management in different cropping systems. Light is an important ecological determinate for germination; the absence of light acts as a soil-depth indicator that prevents many seeds from germinating (Crisraudo et al., 2007). Similarly, an ability to germinate under conditions of moisture stress or high salinity can enable a weed to take advantage of conditions that limit the growth of other species. In preparation for cropping, farmers in many areas burn the cut fallow vegetation or crop residues before the crop is "dibble sown." The heat generated by burning may also affect weed seed germination.

Little information exists about the effect of environmental factors on C. difformis germination in Iran. Some information on the germination ecology of $C$. difformis is available in the Philippines (Chauhan \& Johnson, 2009a). In previous studies, germination of $C$. difformis was stimulated by light and warm fluctuating temperatures. Germination decreased by $50 \%$ of the maximum rate at an osmotic potential of - $0.12 \mathrm{MPa}$ and only $23 \mathrm{mM}$ $\mathrm{NaCl}$ was required to inhibit $50 \%$ of maximum germination (Chauhan \& Johnson, 2009a). Although the information on C. difformis can be useful, observations suggest that the germination requirements of $C$. difformis in Iran are different from those in the Philippines. A better understanding of germination of C. difformis seeds would be useful in developing effective control measures. The objectives of this study were to determine the effect of light, temperature, $\mathrm{pH}$, osmotic stress, and salt stress on C. difformis seed germination and emergence.

\section{MATERIALS AND METHODS}

Experiments were conducted in 2011 at the Seed Technology Laboratory, Department of Agronomy, Gorgan University of Agricultural Science and Natural Resources, Iran (latitude $36^{\circ} 51$ 'N, longitude $54^{\circ} 16^{\prime} \mathrm{E}$ ). Seeds of C. difformis were collected from several rice fields in Golestan, a province of Iran in September 2011. Seeds collected from many randomly selected plants were bulked, cleaned manually, placed in a plastic container, and stored at $5{ }^{\circ} \mathrm{C}$.

\section{General germination test protocols}

Germination of Cyperus difformis was evaluated by placing 50 seeds evenly in a $9 \mathrm{~cm}$ diam Petri dish containing two pieces of Whatman No. 1 filter paper and $5 \mathrm{~mL}$ of distilled water or solutions having different concentrations of salt or osmotic potential or buffered $\mathrm{pH}$. All dishes were sealed with Parafilm to prevent desiccation. The distilled 
water used for replenishing moisture was kept in an incubator to ensure a water temperature consistent with the incubator. Germination was determined after $14 \mathrm{~d}$, at which time seeds with emerged radicles $(>2 \mathrm{~mm})$ were considered to have germinated.

\section{Effect of fluctuating temperature and light on germination}

Germination of freshly harvested seeds was determined in growth chambers under fluctuating day/night temperatures (40/30, $35 / 25,30 / 20$, and $25 / 15^{\circ} \mathrm{C}$ ) in both light/ dark and continuous dark conditions. The photoperiod was set at $12 \mathrm{~h}$ to coincide with the high-temperature phase. For germination in complete darkness, dishes were wrapped in two layers of aluminum foil.

\section{Effect of cold stratification on germination}

Seeds were placed between two pieces of Whatman No. 1 filter paper moistened with distilled water in a 9-cm-diam Petri dish then wrapped in two layers of aluminum foil. Samples were subsequently stored in a refrigerator $\left(5^{\circ} \mathrm{C}\right)$ for $2 \mathrm{wk}$. Germination was determined after the cold stratification period under fluctuating day/night temperature 35/ $25^{\circ} \mathrm{C}$ in both light/dark and continuous dark conditions.

\section{Effect of constant temperature}

The seeds of $C$. difformis were incubated under fluctuating day/night conditions (12/ $12 \mathrm{~h}$ light/dark) at 7 constant temperatures (from $15^{\circ} \mathrm{C}$ to $45^{\circ} \mathrm{C}$ with $5{ }^{\circ} \mathrm{C}$ intervals). Germinated seeds were counted at different time intervals based on observed germination rate under different temperatures, with shorter and longer periods for higher and lower temperatures, respectively. Time estimates taken for cumulative germination to reach $50 \%$ of its maximum at each replicate were interpolated from the germination progress curve versus time. The times for $10 \%$ and $90 \%$ germination were also determined by interpolation and are designated as D10 and D90.

\section{Effect of high temperature "pretreatment" on germination}

A study was conducted to determine the effect of high temperatures, as seeds might experience during the burning of fallow vegetation, on seed germination of C. difformis. Fifty seeds were placed in an oven in an open container at 60,80,100, 120, $140,160,180$, and $200{ }^{\circ} \mathrm{C}$ temperatures for $5 \mathrm{~min}$. The treated seeds were subsequently incubated at $35 / 25{ }^{\circ} \mathrm{C}$ day/night temperature in a $12-\mathrm{h}$ photoperiod for $14 \mathrm{~d}$. In the control treatment, seeds were kept at room temperature $\left(25^{\circ} \mathrm{C}\right)$ before being incubated.

\section{Effect of salt and osmotic stress on germination}

To examine the effect of salinity on C. difformis germination, seeds were placed in dishes containing $5 \mathrm{ml}$ of solution of $0,25,50$, 100,150 and $200 \mathrm{mM} \mathrm{NaCl}$. In a separate study, the effects of moisture stress on seed germination were assessed by incubating seeds in solutions with osmotic potentials of 0 , $-0.1,-0.2,-0.4,-0.6,-0.8$, and $-1 \mathrm{MPa}$, prepared by dissolving polyethylene glycol 8000 in distilled water, as described by Michel (1983). The seeds were incubated at $35 / 25^{\circ} \mathrm{C}$ day/night temperature in a 12 -h photoperiod for $14 \mathrm{~d}$.

\section{Effect of pH of buffered solutions on germination}

Seeds were placed on filter papers soaked with $5 \mathrm{~mL}$ of buffered solutions with $\mathrm{pH}$ ranging from 4 to 9 . Buffer solutions were prepared using potassium hydrogen phthalate in combination with either $0.1 \mathrm{M} \mathrm{HCl}$ or $0.1 \mathrm{M}$ $\mathrm{NaOH}$ to obtain solution $\mathrm{pH}$ levels of $3,4,5$, and 6. A $25 \mathrm{mM}$ sodium tetraborate decahydrate solution was used in combination with control either of $0.1 \mathrm{M} \mathrm{HCl}$ or $0.1 \mathrm{M} \mathrm{NaOH}$ to obtain solution pH levels of 7, 8, and 9 (Shaw et al., 1991). The seeds were incubated at $35 / 25^{\circ} \mathrm{C}$ day/night temperature in a 12 -h photoperiod for $14 \mathrm{~d}$.

\section{Effect of seed burial depth on seedling emergence}

To examine the effect of seed burial depth on seedling emergence, 50 seeds were placed on the soil surface or covered to depths of 0.2 , $0.5,1,2,4$, and $6 \mathrm{~cm}$ with the same soil in $15 \mathrm{~cm}$ diam plastic pots. The soil (clay loam; sand-30\%, silt-36\%, and clay-34\%) used in this experiment was autoclaved and passed 
through a $3 \mathrm{~mm}$ sieve before commencing the experiment. Soil in the pots was moistened initially using a mist sprayer and then subirrigated to maintain adequate soil moisture. Seedling emergence was defined as the coleoptile being visible at the soil surface. The experiment was terminated when no further emergence was recorded for a 3 wk period.

\section{Statistical analyses}

A randomized complete block design with four replications was used in all experiments. Each replicate was arranged on a different shelf or bench in the germination chamber and considered as a block. Protected LSD test at the $5 \%$ probability level was used to evaluate differences between the effect of temperature and light. Regression analysis was used to determine the effect of high temperature pretreatment, salt and osmotic stress, $\mathrm{pH}$, burial depth, and to quantify the cardinal temperatures.

The segmented model (Equation 1) was used to quantify the response of germination rate to temperature and to estimate cardinal temperatures (Ritchie \& NeSmith, 1991).

$$
\begin{aligned}
& f(T)=\frac{T-T_{b}}{T_{0}-T_{b}} \text { if } T_{b}<T \leq T_{b} \\
& f(T)=1-\left(\frac{T-T_{0}}{T_{c}-T_{0}}\right) \text { if } T_{0} \leq T<T_{c} \\
& f(T)=0 \text { if } T \leq T_{b} \text { or } T \geq T_{c}
\end{aligned}
$$

where, $T$ is the temperature, and $T_{b}, T_{o}$ and $T_{c}$ are the base, optimum and ceiling temperatures, respectively. High temperature pretreatment, salt and osmotic stress data showed a sigmoid trend and a three-parameter logistic model was fitted to data (Equation 2).

$$
G=\frac{G_{\max }}{\left\{1+\exp \left[-\frac{x-x_{50}}{G_{\text {rate }}}\right]\right\}}
$$

where $G$ is the percentage germination at temperature and concentration $x$ of $\mathrm{NaCl}$ or osmotic potential, $G_{\max }$ is the maximum germination (\%), $x_{50}$ is the temperature, $\mathrm{NaCl}$ concentration or osmotic potential required for $50 \%$ inhibition of maximum germination and $\mathrm{G}_{\text {rate }}$ indicates the slope of the curve in $x_{50} . \mathrm{pH}$ data were subjected to a binomial model. An exponential function was fitted to the seedling emergence (\%) data (Equation 3).

$$
E=E_{\text {max }} \exp \left(-E_{\text {rate }} x\right)
$$

where $E$ represents emergence (\%), $E_{\max }$ is the maximum emergence and $E_{\text {rate }}$ indicates the slope. Statistical Analysis System (SAS, 1989) and SigmaPlot 8.0 were used for analyzing data.

\section{RESULTS AND DISCUSSION}

\section{Effect of fluctuating temperature and light on germination}

Germination was inhibited by darkness; however, when seeds were subsequently transferred to complete light, they germinated readily. Seed germination response to light varies considerably from species to species. Seeds of some species require light to germinate (Chauhan \& Johnson, 2009a) while others germinate equally in light and dark (Teuton et al., 2004). In the study of Chauhan \& Johnson (2009a), three sedge species (including C. difformis, C. iria and Fimbristylis miliacea) had an absolute light requirement for germination. The results of the present study confirmed that seeds of C. difformis are positively photoblastic. The response to light is thought to be controlled by phytochrome, a light-absorbing pigment within most plants. In photoblastic seeds, light exposure may convert inactive-phytochrome "red" to the active-phytochrome "far-red." Germination of C. difformis seeds in light (optimum condition) suggests that its germination and subsequent emergence in the field will be favored by the presence of seeds at, or near, the soil surface.

Seed germination of $C$. difformis was influenced $(\mathrm{P} \leq 0.01)$ by fluctuating day/night conditions (Figure 1). C. difformis seeds had greater germination at $30 / 20{ }^{\circ} \mathrm{C}(91.5 \%)$, $35 / 25{ }^{\circ} \mathrm{C}(93 \%)$ and $40 / 30{ }^{\circ} \mathrm{C}(88 \%)$ alternating day/night temperatures than at $25 / 15^{\circ} \mathrm{C}$. Germination rate differed among the tested temperatures, with germination being greater at the warmer temperatures $\left(30 / 20^{\circ} \mathrm{C}\right.$ and 


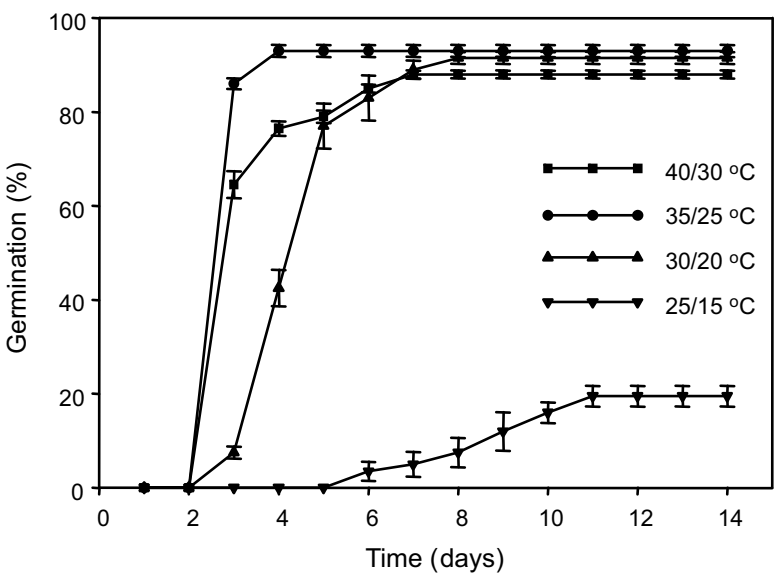

Figure 1 - Effect of fluctuating day/night temperatures (25/15, $30 / 20,35 / 25$ and $40 / 30{ }^{\circ} \mathrm{C}$ ) on seed germination of C. difformis (12/12 h light/dark).

$35 / 25^{\circ} \mathrm{C}$ and $40 / 30{ }^{\circ} \mathrm{C}$ ) than at the coldest temperature $\left(25 / 15{ }^{\circ} \mathrm{C}\right)$. The time to onset of germination and rate of increase were influenced by alternating temperature regimes. Time to onset of germination decreased with increasing temperature. For example, the $35 / 25$ alternating temperature regime conditions caused the fastest onset of germination and highest rate of germination compared to the other three alternating temperature regimes; therefore, $35 / 25{ }^{\circ} \mathrm{C}$ was selected for the subsequent experiments. These data suggest that germination might be limited to a small proportion of seeds in cooler regions of the tropics or during cool seasons. This temperature enhancement of seed germination has been reported in other weed species, including, synedrella (Synedrella nodiflora) (Chauhan \& Johnson, 2009b), rice flatsedge (C. iria) and lesser fimbristylis (F. miliacea) (Chauhan \& Johnson, 2009a). High germination percentages immediately after seed harvest indicating a low level of primary dormancy in this species.

\section{Effect of cold stratification on germination}

While cold stratification is an absolute requirement for germination for some species; in others, it may only improve the percentage and rate of germination and decrease the time to the onset of germination. After 2 wk of cold stratification, the germination percentage of
C. difformis seeds was similar (more than 90\%) in both light/dark and continuous dark conditions under fluctuating day/night temperature $35 / 25{ }^{\circ} \mathrm{C}$. The light requirement for $C$. difformis germination was completely overcome by cold stratification. The ability of cold stratification to overcome the light requirement for germination was previously reported for common groundsel (Senecio vulgaris) (Popay \& Roberts, 1970), short's goldenrod (Solidago shortii) (Walck et al., 1997) and black nightshade (Solanum ptycanthum) (Zhou et al., 2005).

\section{Effect of constant temperature on germination}

In the fluctuating day/night condition (12/ $12 \mathrm{~h}$ light/dark), the highest germination percentiles have been obtained between 25 to $40{ }^{\circ} \mathrm{C}$ and germination reached zero at 15 and $45^{\circ} \mathrm{C}$ (Figure 2). Seeds have the capacity to germinate over a defined range, characteristic for each species; hence, there are clear minimum and maximum temperatures for germination and, between them, a broad range over which germination of all seeds can be attained (Bewley \& Black, 1994).

The influence of temperature on the germination rate was described by a segmented model. The model fitted to relative germination rate vs. mean temperature for 3 percentiles (D10, D50 and D90) is shown in

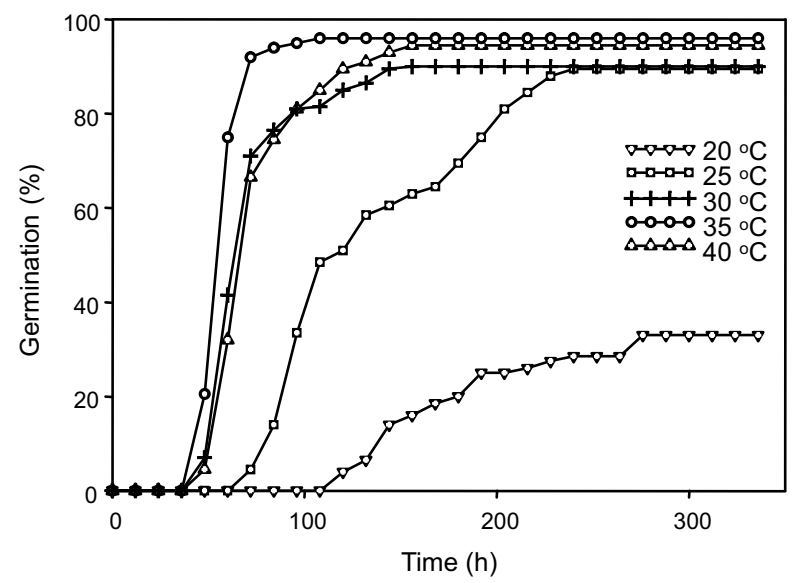

Figure 2 - Effect of constant temperatures (20, 25, 30, 35 and $40{ }^{\circ} \mathrm{C}$ ) on seed germination of $C$. difformis in the fluctuating day/night conditions (12/12 h light/dark). 
Figure 3. According to the segmented model for percentiles of D10, D50 and D90, the base temperature ranged from $14.46^{\circ} \mathrm{C}$ to $15.39^{\circ} \mathrm{C}$. The optimum temperature for all percentiles varied between $36.97{ }^{\circ} \mathrm{C}$ and $38.23^{\circ} \mathrm{C}$. Model outputs, the base and the optimum temperatures were estimated as $14.81{ }^{\circ} \mathrm{C}$ and $37.72{ }^{\circ} \mathrm{C}$, respectively. Ceiling temperature for all percentiles was estimated as $45^{\circ} \mathrm{C}$. In a previous study (Chozin \& Nakagawa, 1988), greater germination of $C$. iria was obtained at a constant temperature of $35^{\circ} \mathrm{C}(69 \%)$ than at $15^{\circ} \mathrm{C}(17 \%)$. Similar types of results were observed for different plants (Vidal et al., 2007; Rizzardi et al., 2009; Ghaderi et al., 2010).

Germination rate is more temperature sensitive than final germination percentage in Setaria lutescens and Amaranthus retroflexus (Bewley \& Black, 1994) similar to our finding for $C$. difformis. Germination rate is most rapid at optimum temperature and declined with decrease and/or increase temperature. A decline in germination rate with decreasing temperature is partly associated with decline in the imbibition rate observed with a reduction in temperature (Bewley \& Black, 1994). Germination rate is affected by the depth of dormancy, imbibition rate and the rate of catabolic and anabolic pathways all of which are directly or indirectly temperature dependent while the maximum seed germination is more affected by the rate of

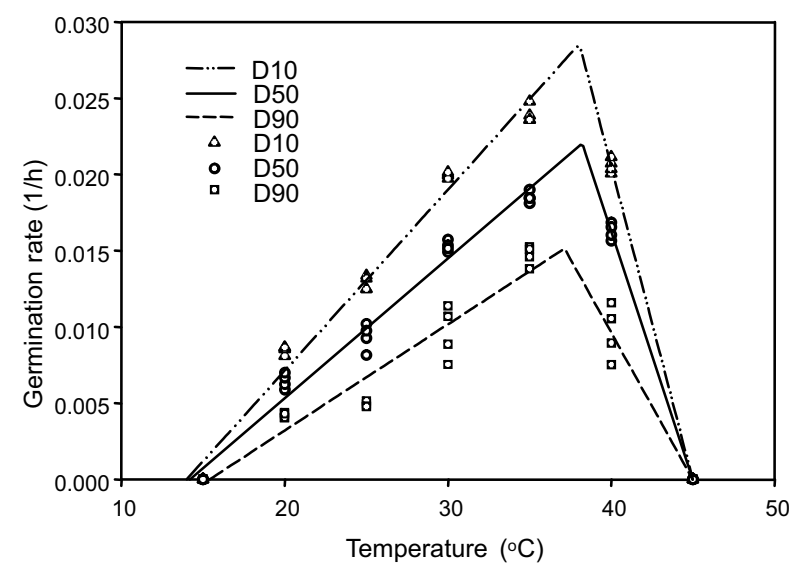

Figure 3 - Predicted (lines) vs. observed (symbols) germination rate of $C$. difformis at different constant temperatures for different germination percentiles (D10, D50 and D90) using the segmented model. rehydration rather than the speed of the physiological pathways affecting cell expansion (Bewley \& Black, 1994).

\section{Effect of high temperature "pretreatment" on germination}

A sigmoid response was observed in the germination of $C$. difformis to the pretreatment of high temperatures (Figure 4). Germination was greater than $74 \%$ up to a temperature of $100{ }^{\circ} \mathrm{C}$ but decreased progressively with further increases in temperature, resulting in no germination after $\geq 160^{\circ} \mathrm{C}$. Estimates from the fitted model indicate that a temperature of $120^{\circ} \mathrm{C}$ was required for a $5 \mathrm{~min}$ interval to inhibit $50 \%$ of maximum germination. Many farmers in tropical countries practice vegetation burning to clear their land of debris before crop planting (Roder et al., 1997). Fireinduced high temperatures can destroy the seeds and can also affect some allelochemicals known to inhibit seed germination (Roder et al., 1997). Burning vegetation can increase surface temperature to $550{ }^{\circ} \mathrm{C}(\mathrm{Cook}, 1939)$; however, temperature can decrease at a rate of $100{ }^{\circ} \mathrm{C} \mathrm{cm}^{-1}$ in the first $5 \mathrm{~cm}$ below the soil surface (Sanchez, 1976). Assuming these values, although seeds on the soil surface might be destroyed by high temperature, seeds

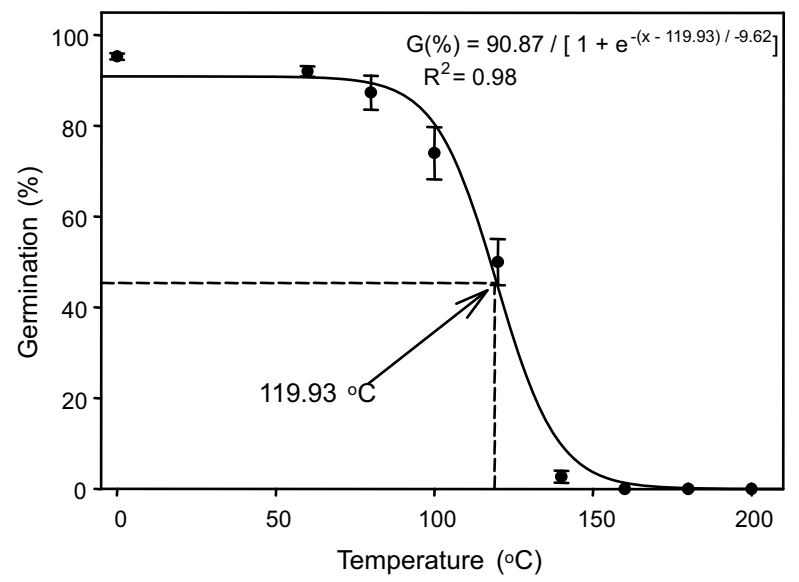

Figure 4 - Effect of 5 min exposures to a range of oven temperatures on seed germination of $C$. difformis after $14 \mathrm{~d}$ of incubation in light/dark at $35 / 25^{\circ} \mathrm{C}$ fluctuating day/night temperature. The line represents a three-parameter sigmoid model fitted to the data. The temperature required for $50 \%$ inhibition of maximum germination was estimated as $119.93{ }^{\circ} \mathrm{C}$. 
buried below $4 \mathrm{~cm}$ could escape from the effect of heat. These seeds can remain dormant while buried; however, they can germinate when brought onto the soil surface by intercultivation or tillage operations and exposed to light.

\section{Effect of Salt and osmotic stress on germination}

A three-parameter sigmoid model was fitted to the germination percentage obtained at different concentrations of $\mathrm{NaCl}$ (Figure 5). Germination was greater than $85 \%$ up to the concentration of $100 \mathrm{mM} \mathrm{NaCl} ; 29 \%$ germination occurred at $150 \mathrm{mM} \mathrm{NaCl}$, although germination was completely inhibited at $200 \mathrm{mM} \mathrm{NaCl}$. The concentration required for $50 \%$ inhibition of maximum germination was $135.57 \mathrm{mM} \mathrm{NaCl}$. Salinity is a major abiotic constraint for plants and can negatively affect important physiological processes. In addition to physiological processes in the plants, sodium can alter soil structure and fertility by replacing calcium and magnesium in the anion exchange process, and that leads to nutrient and water stress (DiTommaso, 2004).

A three-parameter sigmoid model was fitted to the germination values obtained at different osmotic potentials (Figure 6).

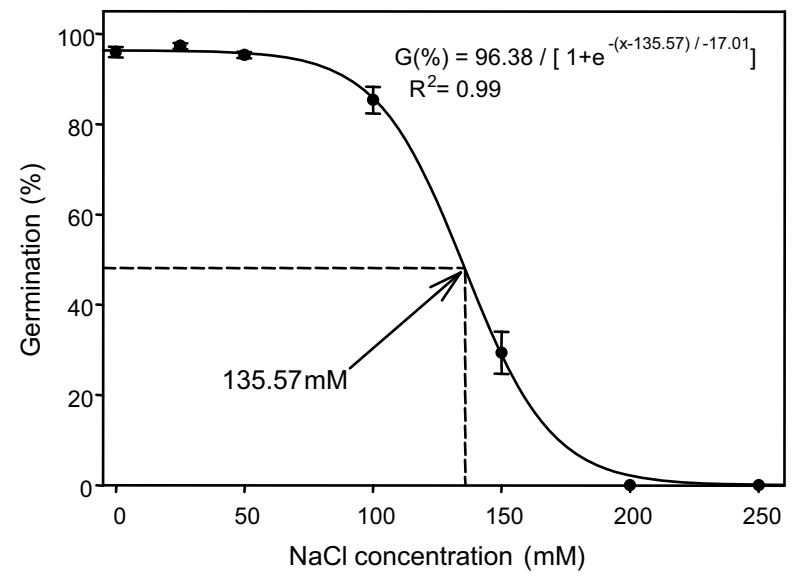

Figure 5 - Effect of $\mathrm{NaCl}$ concentration on seed germination of C. difformis after $14 \mathrm{~d}$ of incubation in light/dark at $35 / 25^{\circ} \mathrm{C}$ fluctuating day/night temperature. The line represents a three-parameter sigmoid model fitted to the data. The salt concentration required for $50 \%$ inhibition of maximum germination was estimated as $135.57 \mathrm{mM}$.
Germination decreased from 94 to $10 \%$ as osmotic potential decreased from 0 to $-0.6 \mathrm{MPa}$, and it was completely inhibited at osmotic potential of $-0.8 \mathrm{MPa}$. The osmotic potential required for $50 \%$ inhibition of the maximum germination was $-0.47 \mathrm{MPa}$. As water potential decreased beyond $-0.4 \mathrm{MPa}$, germination decreased sharply, suggesting that C. difformis favors a moist environment for germination. This is supported by the occurrence of this weed in lowland fields where soil moisture is high, whereas in upland fields germination would most likely occur in the rainy season.

\section{Effect of pH of buffered solutions on germination}

A quadratic model was fitted to the germination values obtained in response to $\mathrm{pH}$ of buffered solution (Figure 7). Seed germination has occurred in a range of $\mathrm{pH}$ between 4 and 9 , but the maximum germination (89\%) was observed at $\mathrm{pH}=6$. Germination decreased to 80 and $12 \%$ at $\mathrm{pH} 4$ and 9 , respectively. Seed of many species germinate to high percentages over a wide range of $\mathrm{pH}$ values (Jain \& Singh, 1989; Souza Filho et al., 2001), but those of others germinate to high percentages only at specific $\mathrm{pH}$ values (Wilson Jr., 1979; Chachalis $\&$ Reddy, 2000).These results suggest that seeds

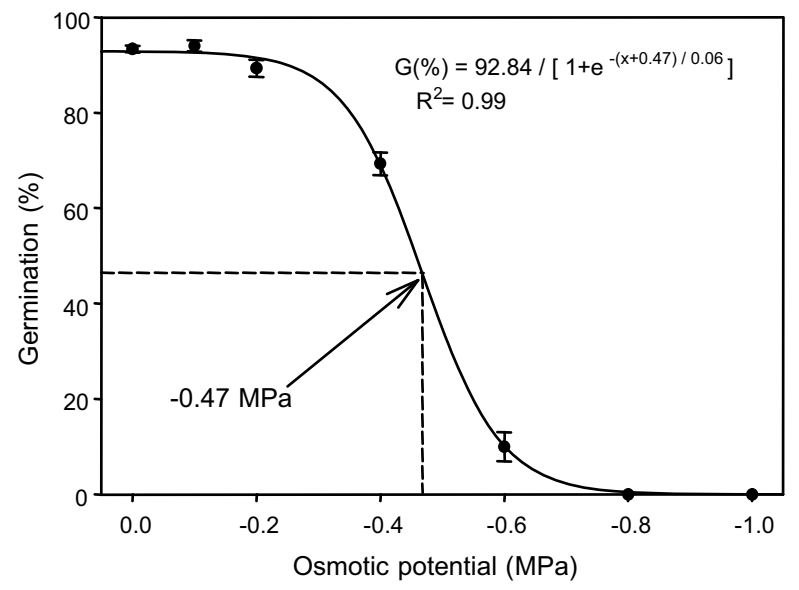

Figure 6 - Effect of osmotic potential on seed germination of C. difformis after $14 \mathrm{~d}$ of incubation in light/dark at $35 / 25^{\circ} \mathrm{C}$ fluctuating day/night temperature. The line represents a three-parameter sigmoid model fitted to the data. The osmotic potential required for $50 \%$ inhibition of the maximum germination was estimated as $-0.47 \mathrm{MPa}$. 


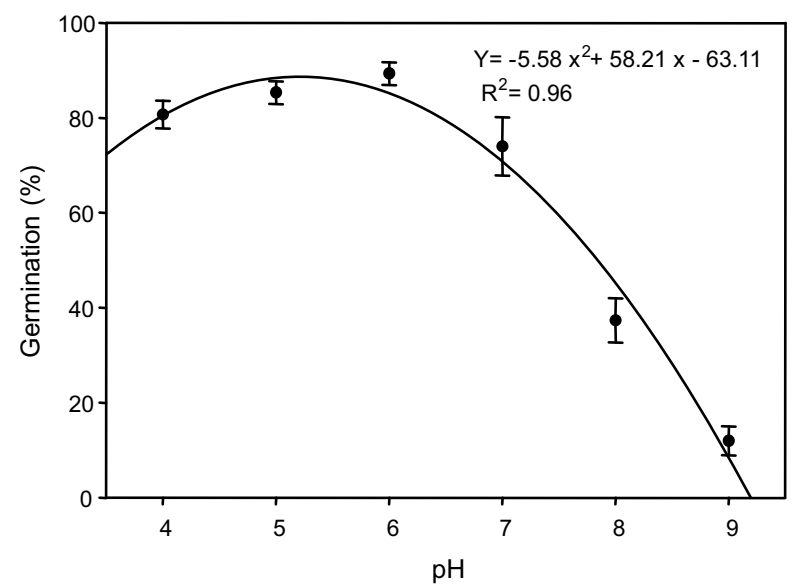

Figure 7 - Effect of pH of buffered solution on seed germination of $C$. difformis after $14 \mathrm{~d}$ of incubation in light/dark at 35/ $25{ }^{\circ} \mathrm{C}$ fluctuating day/night temperature. The line represents a quadratic model fitted to the data.

of $C$. difformis cannot survive in very alkaline conditions and that a $\mathrm{pH}$ below 7 was favorable for germination of $C$. difformis.

\section{Effect of seed burial depth on seedling emergence}

Seed burial depth greatly affected seedling emergence of $C$. difformis (Figure 8). The greatest level of emergence $(67 \%)$ was observed for seeds placed on the soil surface. Emergence decreased sharply with increasing burial depth, and no seedlings emerged at burial depths of $1 \mathrm{~cm}$ or greater. These results corroborate those of the studies on temperature and light. It has been reported that very little light is transmitted by any type of soil at a depth greater than $4 \mathrm{~mm}$ (Benvenuti, 1995). Because of the absolute requirement for light, limited light penetration may be a major reason for no emergence from buried seeds. In addition, the magnitude of temperature fluctuation in soils increases near the soil surface and declines in the soil profile (Rubin \& Benjamin, 1984). Hypoxia and low rates of gaseous diffusion at deeper depths could be other reasons for the lack of emergence (Benvenuti, 2003). Besides, smallseeded species such as $C$. difformis may not have enough reserves to support seedling emergence from depth.

In conclusion, the highest germination levels in C. difformis at $30 / 20{ }^{\circ} \mathrm{C}, 35 / 25^{\circ} \mathrm{C}$ and $40 / 30{ }^{\circ} \mathrm{C}$ alternating temperatures indicating that higher range of the tested temperatures favour germination of this species. Germination of freshly harvested seeds was inhibited by darkness. Our results show that 2 wk of cold stratification overcome the light requirement for germination. Segmented model outputs, the base, the optimum and the ceiling temperatures were estimated as $14.81,37.72$ and $45^{\circ} \mathrm{C}$, respectively. Greater emergence from seeds placed on the soil surface suggests that no-till farming practices would favour emergence of C. difformis in the field. As this species could not emerge from a depth of $1 \mathrm{~cm}$, shallow tillage operations that bury seeds below this depth could be an option to limit the germination of C. difformis. This may have practical significance in weed management systems as tillage options may be devised to limit the portion of the soil seed bank exposed to the surface layers and thus the ability to germinate. It should be noted that germination responses to some factors (e.g., osmotic potential and salinity) were different between our study and the study conducted with seeds of the Philippines population (Chauhan \& Johnson, 2009a). This suggests that C. difformis could be polymorphic in its response to some factors, and further studies are required to elucidate this. If differences between populations exist, this could warrant different management practices in different countries.

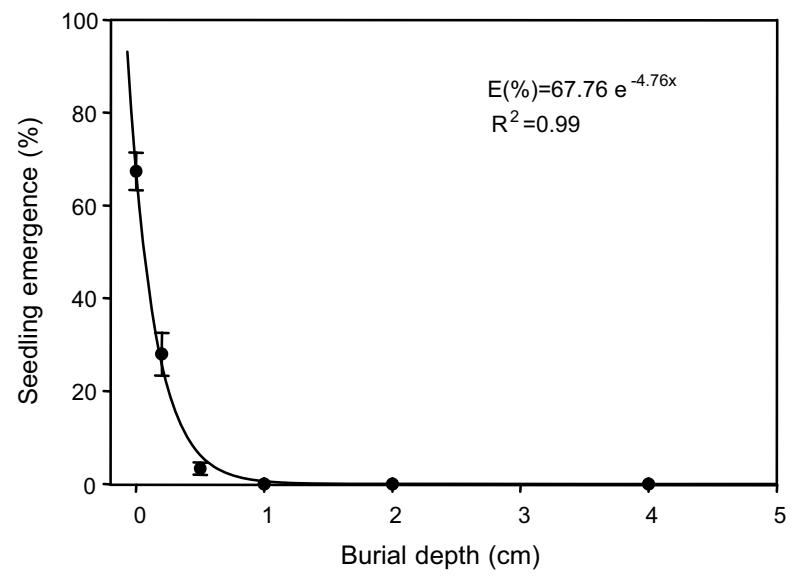

Figure 8 - Effect of seed burial at various soil depths on seedling emergence of $C$. difformis after $21 \mathrm{~d}$ of incubation in light/ dark at $35 / 25{ }^{\circ} \mathrm{C}$ fluctuating day/night temperature. The line represents an exponential curve fitted to the data. 


\section{LITERATURE CITED}

ALVARADO, V.; BRADFORD, K. J. A hydrothermal time model explains the cardinal temperatures for seed germination. Plant Cell. Environ., v. 25, n. 8, p. 1061-1069, 2002.

BASKIN, C. C.; BASKIN, J. M. Seeds: ecology, biogeography and evolution of dormancy and germination. New York: Academic Press, 1998. p. 666.

BENVENUTI, S. Soil light penetration and dormancy of jimsonweed (Datura stramonium) seeds. Weed Sci., v. 43, n. 3, p. 389-393, 1995.

BENVENUTI, S. Soil texture involvement in germination and emergence of buried weed seeds. Agron. J., v. 95, n. 1, p. 191-198, 2003.

BEWLEY, J. D.; BLACK, M. Seeds: physiology of development and germination. 2.ed. New York: Plenum Press, 1994. p. 445.

CHACHALIS, D.; REDDY, K. N. Factors affecting Campsis radicans seed germination and seedling emergence. Weed Sci. v. 48, n. 2, p. 212-216, 2000.

CHAUHAN, B. S.; JOHNSON, D. E. Ecological studies on Cyperus difformis, Cyperus iria and Fimbristylis miliacea: three troublesome annual sedge weeds of rice. Ann. Appl. Biol., v. 155, n. 1, p. 103-112, 2009a.

CHAUHAN, B. S.; JOHNSON, D. E. Seed germination and seedling emergence of synedrella (synedrella nodiflora) in a tropical environment. Weed Sci., v. 57, n. 1, p. 36-42, 2009b.

CHOZIN, M. A.; NAKAGAWA, K. Autecological studies on Cyperus iria L. and C. microiria Steud., annual Cyperaceous weeds. Weed Res., v. 33, n. 1, p. 23-30, 1988.

COOK, L. A contribution to our information on grass burning. Southern. Afr. J. Sci., v. 36, n. 1, p. 270-282, 1939.

CRISRAUDO, A. et al. Effects of after harvest period and environmental factors on seed dormancy of Amaranthus species. Weed Res., v. 47, n. 4, p. 327-334, 2007.

DITOMMASO, A. Germination behavior of common ragweed (Ambrosia artemisiifolia) populations across a range of salinities. Weed Sci., v. 52, n. 6, p. 1002-1009, 2004.

GHADERI, F. A. et al. Influence of environmental factors on seed germination and seedling emergence of yellow sweet clover (melilotus officinalis). Planta Daninha, v. 28, n. 3, p. 463-469, 2010.

GUAN, B. et al. Germination responses of Medicago ruthenica seeds to salinity, alkalinity and temperature. J. Arid Environ., v. 73, n. 1, p. 135-138, 2009.

HOLM, L. G. et al. The world's worst weeds: distribution and biology. Honolulu: University of Hawaii Press, 1991. p. 609.
JAIN, R.; SINGH, M. Factors affecting goatweed (Scoparia dulcis) seed germination. Weed Sci., v. 37, n. 6, p. 766-770, 1989.

MICHEL, B. E. Evaluation of water potential of solution of polyethylene glycol 8000 both in absence and presence of other solutes. Plant Physiol., v. 72, n. 1, p. 66-70, 1983.

POPAY, A. I.; ROBERTS, E. H. Factors involved in the dormancy and germination of Capsella bursa-pastoris (L.) Medik. and Senecio vulgaris (L.). J. Ecol., v. 58, n. 1, p. 103-121, 1970.

RAO, A. N. et al. Weed management in direct-seeded rice. Adv. Agron., v. 93, n. 1, p. 153-255, 2007.

RITCHIE, J. T.; NESMITH, D. S. Temperature and crop development. In: HANKS, J.; RITCHIE, J. T., (Ed.). Modeling plant and soil systems. Madison: ASA, CSSSA, SSSA, 1991. p. 452.

RIZZARDI, M. A. et al. Effect of cardinal temperature and water potential on morning glory (Ipomoea triloba) seed germination. Planta Daninha, v. 27, n. 1, p. 13-21, 2009.

RODER, W. et al. Weeds in slash-and-burn rice fields in northern Laos. Weed Res., v. 37, n. 2, p. 111-119, 1997.

RUBIN, B.; BENJAMIN, A. Solar heating of the soil: involvement of environmental factors in the weed control process. Weed Sci., v. 32, n. 1, p. 138-142, 1984.

SANCHEZ, P. A. Soil management in shifting cultivation areas. In: SANCHEZ, P. A. (Ed.). Properties and management of soils in the tropics. New York: John Wiley \& Sons, 1976. p.347-412.

SAS Institute. User's guide. Version 6. 4.ed. Cary: 1989. p. 943.

SHAW, D. R. et al. Redvine (Brunnichia ovata) germination and emergence. Weed Sci., v. 39, n. 1, p. 33-36, 1991.

SOUZA FILHO, A. P. S. et al. Seed germination in weeds from cultivated pasture areas: Mimosa pudica and Ipomoea asarifolia. Planta Daninha, v. 19, n. 1, p. 23-31, 2001.

TEUTON T. C. et al. Factors affecting seed germination of tropical signalgrass (Urochloa subquadripara). Weed Sci., v. 52, n. 3, p. 376-381, 2004.

VIDAL, R. A. et al. Impact of temperature, light and seed depth on emergence and germination of Conyza bonariensis and Conyza Canadensis resistant to glyphosate.

Planta Daninha, v. 25, n. 2, p. 309-315, 2007.

WALCK, J. L. et al. A comparative study of the seed germination biology of a narrow endemic and two geographically-widespread species of Solidago (Asteraceae). 1. Germination phenology and effect of cold stratification on germination. Seed Sci. Res., v. 7, n. 1, p. 47-58, 1997. 
WILSON JR., R. G. Germination and seedling development of Canada thistle (Cirsium arvense). Weed Sci., v. 27, n. 2, p. 146-151, 1979.
ZHOU, J. et al. Factors affecting eastern black nightshade (Solanum ptycanthum) seed germination. Weed Sci., v. 53, n. 1, p. 41-45, 2005. 